\title{
Municipal Waste Management Strategy Review and Waste-to-Energy Potentials in New Zealand
}

\author{
Jean-François Perrot ${ }^{\mathbb{D}}$ and Alison Subiantoro * \\ Department of Mechanical Engineering, The University of Auckland, 20 Symonds Street, Auckland 1010, \\ New Zealand; jper848@aucklanduni.ac.nz \\ * Correspondence: a.subiantoro@auckland.ac.nz
}

Received: 7 August 2018; Accepted: 27 August 2018; Published: 31 August 2018

\begin{abstract}
Municipal waste management and Waste-to-Energy (WtE) potentials in New Zealand are discussed. The existing main waste management strategy of New Zealand is to reduce, reuse and recycle waste. Most of the remaining waste is currently disposed of in landfills. WtE options were explored in this study as a more sustainable waste treatment alternative in the country, while making use of the annual 30.8 petajoule of available waste energy in New Zealand. Four WtE technology options were discussed and compared, namely incineration, anaerobic digestion, gasification and pyrolysis. The aspects in comparison were air pollution, cost, side products, capacity, commercial maturity, energy efficiency and type of waste treated. Special emphasis was given to environment-friendliness and cost. From the comparison, it was found that anaerobic digestion seems to be the most attractive solution for the country as it is environment-friendly, economical and the concept is consistent with New Zealand's existing waste management strategy. The major limitations of anaerobic digestion are its low energy production efficiency and its limited waste treatment capacity. Hence, an effective national waste reduction and recycling strategy is crucial for the success of this waste management option.
\end{abstract}

Keywords: municipal waste; energy; New Zealand; incineration; anaerobic digestion; pyrolysis; gasification

\section{Introduction}

The World Bank predicted the global municipal waste generation will increase from 1.3 billion tons per year in 2012 to 2.2 billion tons per year in 2025 [1]. If not managed properly, this will create various social and environmental problems, including air, soil and water pollutions, the spread of diseases and the release of greenhouse gases, particularly methane, to the atmosphere that contributes to global warming.

In New Zealand, waste management is an especially pressing issue. According to the World Bank, the country was the most wasteful nation in the developed world and ranked number 10 globally in terms of municipal waste generation per capita in 2012 and is projected to remain so for the foreseeable future [2]. This high amount of waste is due to the fact that the nation is a big consumer of resources and import high volumes of goods, which is typical among the OECD (The Organisation for Economic Co-operation and Development) members [3], with a relatively small population of less than 5 million people in 2018 [4]. The waste issue in the country is recently worsened by China's decision in 2017 to restrict imports of plastic, which directly impacts the 30,000 tons of plastic waste New Zealand used to export annually [5].

Currently, the main strategy adopted by New Zealand's government regarding its waste management strategy is to reduce, recycle and reuse waste [6]. Most of the non-recyclable and/or non-reusable waste ends up in landfills [7]. Although landfilling maybe the most economical solution in the short term, its long-term impacts to the environment and its sustainability are problematic. 
Among the options explored around the world to face the waste issue, energy generation from municipal waste is one of the most attractive solutions [8]. Furthermore, there is a good symmetry between the ever-increasing energy demand and the amount of municipal waste generated, making the Waste-to-Energy (WtE) option even more attractive. It is noted, however, that the concept has its own issues that will be discussed further below.

Comprehensive reviews on various WtE technologies are available in the literature $[9,10]$. Reviews on waste management issues in Europe [11,12], Africa [13], Asia [14] and in developing countries [15] are also available. Country-specific studies, such as that in China [16], India [17], Turkey [18], USA [19], Colombia [20], Malaysia [21], Thailand [22] and Saudi Arabia [23], among others, can be found too. In general, it can be seen that waste management is a growing challenge among the countries. A number of government policies have been put in place to overcome this issue with varying degrees of effectiveness, and various options have been considered to reduce the amount of waste that ends up in landfills, including recycling and WtE technologies. It is noted that incineration is still the most common method due to its effectiveness. To the authors' knowledge, no such study is available for New Zealand and its unique contexts. The status of zero-waste management strategy in New Zealand up to 2002 was mentioned very briefly in Reference [24]. A somewhat related analysis of waste management in New Zealand is available [3], but the emphasis was on key policies and government programs. Moreover, there have been new developments in the country since the article was published in 2009, including the significant population increase and the shift towards better environment management in recent years. The goal of this study is to investigate the potentials of $\mathrm{WtE}$ technology to solve the waste issue of New Zealand. To reach this objective, a review of the current waste management condition in the country is carried out. Data from various sources are collected to draw a comprehensive picture of the national waste situation. Afterwards, the country's waste strategy, including some of the relevant laws and regulations, are presented and its effectiveness is discussed. The available WtE technologies in the world are then reviewed. The technologies include: waste incineration, anaerobic digestion, pyrolysis and gasification. Their strengths and weaknesses are compared based on the contexts of New Zealand. The comparisons will focus on their air pollution, cost, side products, capacity, commercial maturity, efficiency and type of waste treated associated with each technology.

\section{Waste Management in New Zealand}

According to an OECD report in 2017 [25], the amount of municipal solid waste generated in New Zealand has increased steadily alongside population, gross domestic product and private final consumption in recent years. Its waste generation per capita is currently among the highest in the OECD and the majority of the waste is landfilled. From 2010-15, it was reported that the amount of waste per capita of New Zealand grew by more than $20 \%$ [26], as can be seen in Table 1 . Here, municipal waste is defined as the waste collected and treated by municipalities. It covers the waste from households, including bulky waste, similar waste from commerce and trade, office buildings, institutions and small businesses, as well as yard and garden waste, street sweepings, the contents of litter containers and market cleansing waste (if managed as household waste). Hence, the figures exclude waste materials that are recovered, reused or recycled. As can be observed, the amount of waste grew with years although there was a slight dip from 2010-11. Based on this trend, it was predicted that the total amount of municipal waste generation in New Zealand will be doubled in 30 years. 
Table 1. Municipal waste of New Zealand from 2010-15 (data are extracted from OECD database [26]).

\begin{tabular}{ccc}
\hline Year & Total Amount of Waste (Millions of tons) & Amount of Waste Per Capita (kg) \\
\hline 2010 & 2.532 & 582.0 \\
2011 & 2.512 & 573.0 \\
2012 & 2.514 & 570.3 \\
2013 & 2.684 & 604.2 \\
2014 & 2.931 & 649.9 \\
2015 & 3.221 & 701.3 \\
\hline
\end{tabular}

A report from the country's Ministry for the Environment [7] explained that the reduction in the amount of municipal waste in the early 2010s was because individual, community and local and central government initiatives had been successful in diverting large amounts of waste from landfills through recovery and recycling of items, among others. Nevertheless, the report also states that there was still approximately $75 \%$ of the waste disposed of to landfills that could be potentially diverted. Further reductions were also possible at other stages of a product's life cycle. As shall be discussed later, this strategy of waste minimization is currently the government's main waste management strategy.

It is difficult to get accurate data on the proportion of the municipal waste that ends up in landfills. However, based on the data from the Ministry for the Environment [7], there were 2.531 million tons and 2.461 million tons of waste disposed of to landfills in 2010 and 2011, respectively. Comparing these data with OECD's data on the amount of waste produced [26] in Table 1, it can be seen that more than $97 \%$ of the waste are disposed of into landfills.

The waste composition data in New Zealand's landfills can be gathered from reports that have been released by the various regional councils in the country. Perrot [27] has compiled the available data from 2011-17 and the summary is presented in Table 2. The types of waste have been categorized into those with and without energy generation potentials. In total, $78.2 \%$ of the waste can be used for power generation in WtE plants. Organic materials represent almost one third of the total waste in landfills, while timber and plastic represent one fourth of the waste.

Table 2. Waste composition of landfills in New Zealand between 2011 and 2017 (data are adapted from regional council reports as compiled by Perrot [27]).

\begin{tabular}{cc}
\hline Type of Waste & Percentage \\
\hline \multicolumn{2}{c}{ Waste with energy potential } \\
\hline Organic & $30.4 \%$ \\
Timber & $14.1 \%$ \\
Plastic & $12.1 \%$ \\
Paper & $9.0 \%$ \\
Nappies and sanitary & $6.3 \%$ \\
Textiles & $5.4 \%$ \\
Rubber & $0.9 \%$ \\
\hline Waste with no energy potential \\
\hline Rubble and concrete & $10.0 \%$ \\
Potential hazardous & $4.4 \%$ \\
Glass & $3.3 \%$ \\
Metal & $3.1 \%$ \\
\hline
\end{tabular}

At the moment, the waste management plans realized by regional councils in New Zealand are mainly governed by the Waste Minimization Act of 2008 [28]. The act encourages the reduction of waste generated and disposed of in the country. The aim is to protect the environment from harm and provide environmental, social, economic and cultural benefits. To achieve this goal, several measures have been taken over the years: 
- Imposition of a levy on all waste disposed of in landfills to generate funding to help local government, communities and businesses to minimize waste.

- Establishment of product stewardship schemes. This strategy gives the responsibility to a product designer, seller or user to minimize its impact on the environment.

- Regulations made to control the disposal of products, materials or waste.

- Empowerment of the responsibilities of regional authorities that need to write a waste assessment every six years.

- Creation of the Waste Advisory Board to give independent advice to the Minister for the Environment on matters related to waste minimization.

The country's Ministry for the Environment has also formulized New Zealand's Waste Strategy in 2002 and revised it in 2010 [6]. The strategy has a vision towards zero waste and a sustainable New Zealand through three main goals. They are to lower the costs and risks of waste to society, to reduce the environmental damage from the generation and disposal of waste, and to increase economic benefit by using material more efficiently. The strategy focuses more on waste prevention rather than on waste disposal and adopts this waste treatment hierarchy: reduction (most desirable option), reuse, recycle, recovery, treatment, and lastly, disposal (least desirable option).

In response, various regional councils in the country have taken these steps to achieve the zero-waste objective by 2040 [27]:

- the development of additional recycling facilities,

- the reduction of green waste quantities,

- the education of the population about the waste hierarchy and the need to consume less,

- the need to gather more data about the waste situation in each region,

- the reduction of illegal dumping,

- the development of resource recovery networks.

With these regulations and instruments in place, there has been considerable progress in access to recycling services and environmental controls around disposal facilities over the years. However, as can be seen from the waste generation data in Table 1, there has been less success in the overall reduction of waste generation in New Zealand.

In terms of waste treatment, landfilling is still the most common method of solid waste disposal in the country, although there have been discussions about alternative solutions, including various WtE options. Among the alternatives, WtE incineration technology is the most mature [10]. Nevertheless, New Zealand has traditionally been reluctant to commit into WtE incineration plants. Some arguments that have been raised against the technology by the Waste Management Institute of New Zealand [29] are:

- Community perception: Waste incineration has the potential to cause harm to both the environment and human health. However, the institute also noted that with today's modern and efficient technologies these health and environmental concerns can be largely avoided through treatment and mitigation of emissions. Therefore, through engagement and consultation with affected communities, these perceptual issues can be overcome.

- Cannibalizing recycling programs: The development of WtE plants contradicts with the recycling policy of New Zealand because those plants always need a lot of feedstock to run at maximum capacity.

- Consistency of feedstock issue: New Zealand has a relatively large land area as compared to its population. Hence, getting consistent volumes of waste are difficult. Only in an area such as Auckland, there is certainly no shortage of waste. However, there are many and varied disposal options already in existence competing for the same waste, many of which are likely to be far cheaper solutions.

- Cost issue: Landfilling remains New Zealand's predominant mechanism for waste disposal as it is cost-effective. Only with significant waste disposal levies through regulatory intervention, a WtE plant can be considered economically attractive. 


\section{Waste-to-Energy Technologies and Their Status in New Zealand}

As laid out in the previous section, New Zealand is highly reliant on landfilling to treat its waste. At the same time, waste generation in the country is growing steadily and China's recent decision not to import plastic waste anymore will force the country to reconsider its waste management strategy sooner or later. The authors believe that it is time to review the WtE options to solve New Zealand's waste situation. The existing concerns against the technology, particularly to WtE incineration plants, are noted and will be addressed.

Obviously, another added benefit for New Zealand from WtE technologies is the additional renewable energy source available to reduce its dependency on fossil fuels. It is noted that around $85 \%$ of the electricity and $40 \%$ of the total energy supply in New Zealand were already generated from renewable sources in 2016 [30]. Fossil fuels are still used to produce electricity during dry seasons. Waste can be a very attractive fuel alternative as its supply is relatively unaffected by the seasons.

\subsection{Incineration}

The most mature technology to extract energy from waste is incineration [10]. The process involves burning of waste in furnaces and using the heat produced to generate useful power (in the form of electricity or heat). By-products of the process are ash and exhaust gas. The ash residue can be further processed to remove metals for recycling and the remainder can be used for construction materials. Most modern plants currently have an energy efficiency of around 30\% [10]. Integrated WtE-Gas Turbines power plants have been proposed recently to increase the energy efficiency to more than $40 \%$ and in 2012, there are three such plants in Spain, Netherlands and Japan [31]. Although the technology is not yet matured, the integrated gas turbine system seems to be the future of WtE incineration technologies.

The main advantage of incineration as compared to the other options is its effectiveness to remove waste in terms of capacity, type of waste treated and volume reduction [32]. The potential economic values of the residues are an added benefit of the technology. The weaknesses of WtE incinerators are related to their cost, social and environmental issues [29]. WtE incineration plants are relatively expensive to build and communities are usually reluctant to live near incinerators. The incineration of waste releases polluting metals, dioxins and toxic gases that are harmful for human health to the atmosphere. However, it is noted that the quantities released have decreased in the past few years because of stricter rules imposed by governments and the technological progress made in this field [33,34].

WtE incineration technology has been implemented successfully in Europe. The biggest investors include France, Germany, the United Kingdom, Italy and Sweden [35]. Incineration allows these investors to reduce the volume of waste disposed in landfills by $90 \%$. In European Union (EU) countries, $26 \%$ of waste is used to generate energy in 2015 [36]. This energetic valorization represents $1.3 \%$ of the final electricity consumption and $8.9 \%$ of the heat consumption. $409 \mathrm{WtE}$ plants were counted in the EU in 2012 that burned 74 million of tons of waste producing 30 TWh of electricity and 74 TWh of heat [36].

The waste management case of Sweden [37] is particularly relevant for New Zealand and the concerns raised by the authorities. Like New Zealand, Sweden puts a lot of emphasis on recycling and has been very successful, with half of the waste in Sweden is recycled every year. Contrary to New Zealand, however, the rest of the waste is converted to energy in the $33 \mathrm{WtE}$ plants in the country, leaving only about $1 \%$ of waste in landfills [37]. The waste treatment systems have been so effective that Sweden also imports waste from other countries that are willing to pay the price to feed its plants.

In New Zealand, there are currently only three high-temperature hazardous waste incinerators in operation. They are at Auckland International Airport, in New Plymouth and near Christchurch International airport [27]. 


\subsection{Anaerobic Digestion}

Another technology that is available to create energy from waste is anaerobic digestion. It is a process involving the decomposition of putrescible materials by bacteria acting without the presence of air. Biogas, which is a renewable energy comprised of methane and carbon dioxide, is generated from the process. The main advantages of anaerobic digestion over incineration are its lower emissions of carbon dioxide, the possible valorization of organic waste for soil conditioners and the reduced odor emissions [32]. From life cycle perspective, anaerobic digestion is more attractive than incineration too [38]. The main limitation is that the process is slow. Hence, it may not be practical to rely solely on anaerobic digestion to remove all the waste from a country. Furthermore, it can only treat biodegradable waste or organic fraction of municipal solid waste (OFMSW) [39].

Around the world, there were approximately 12,000 biogas plants in 2016 and is expected to grow to 15,000 by 2025 [40]. 90\% of those plants are in Europe and the strongest biogas markets are in Germany, France, Italy and Poland [40]. However, this technology is less mature and is less popular than the $\mathrm{WtE}$ incineration alternative. Furthermore, there are unique challenges to its implementation in urban areas [41].

In New Zealand, the biogas sector is currently growing. In 2015, the estimated total amount of methane collected and transformed into biogas was around $4.7 \mathrm{PJ}$ (petajoule), which can power 40,000 households [42]. There are 31 main biogas plants in New Zealand treating waste from landfills, sewage, wastewater, rural and industrial waste [42].

\subsection{Gasification and Pyrolysis}

Gasification process involves the conversion of an organic compound into a gas mixture (syngas) and a solid by-product (char). The conversion is made at a temperature of more than $650{ }^{\circ} \mathrm{C}$ [32]. Syngas has a high heating power and can be used for power generation or biofuel production. Char is a mixture of organic carbon and ash. Several gasification technologies exist around the world and what differentiates them is the reactors used and the operations realized [43].

Pyrolysis is thermal degradation with a limited supply of, or in the complete absence of, an oxidizing agent at a temperature of between $400{ }^{\circ} \mathrm{C}$ and $1000{ }^{\circ} \mathrm{C}$ [44]. The conversion can produce three products: pyrolysis gas, pyrolysis liquid and solid coke. The WtE potential efficiency of pyrolysis is similar to that of gasification and both techniques can treat all kind of municipal waste. However, these technologies are less matured as compared to anaerobic digestion and incineration [44].

In New Zealand, there have been small-scale gasification and pyrolysis waste treatment projects, particularly for wood waste $[45,46]$. However, to the authors' knowledge, there is no large-scale gasification/pyrolysis plant in the country as of 2018.

\section{Waste-to-Energy Generation Potentials in New Zealand}

From the above discussions, there are at least four major WtE technologies available, i.e., incineration, anaerobic digestion, gasification and pyrolysis. These technologies will now be compared. The comparison includes the energy potential and suitability of each technology in the context of New Zealand.

\subsection{Energy Potential from Municipal Waste in New Zealand}

In 2015, New Zealand generated 3.221 million tons of municipal waste [26]. To get an estimation of the energy that could be generated from this waste, a calculation was carried out. Table 3 shows the amount of each waste type generated annually in the New Zealand (data are adapted from Reference [27]), the heating value of each kind of waste (values are approximated based on Reference [47]) and the corresponding available energy. In total, there is more than $30.8 \mathrm{PJ}$ of energy available per year from waste in New Zealand. In comparison, the total energy demand of the country was 577.6 PJ in 2016, of which 25.5 PJ, 270.9 PJ and 81.3 PJ was supplied by coal, oil and natural gas, 
respectively [30]. Therefore, the available energy from municipal waste in New Zealand is comparable to the energy demand provided by coal.

Table 3. Annual municipal waste energy potential of New Zealand.

\begin{tabular}{ccccc}
\hline & $\begin{array}{c}\text { Percentage } \\
(\mathbf{\%})[27]\end{array}$ & $\begin{array}{c}\text { Amount of } \\
\text { Waste (tons) }\end{array}$ & $\begin{array}{c}\text { Heating Value } \\
\text { (MJ/kg) [47] }\end{array}$ & Energy Contained (GJ) \\
\hline $\begin{array}{c}\text { Organic } \\
\text { Paper, nappies and }\end{array}$ & 30.4 & 979,184 & 3 & $2,937,552$ \\
sanitary & 15.3 & 492,813 & 16 & $7,885,008$ \\
Timber & 14.1 & 454,161 & 6 & $2,724,966$ \\
Plastic & 12.1 & 389,741 & 35 & $13,640,600$ \\
Rubber & 0.9 & 28,989 & 14 & 405,846 \\
Textiles & 5.4 & 173,934 & 19 & $3,304,746$ \\
\hline Total & & & $30,898,718$ \\
\hline
\end{tabular}

To estimate the potential energy that can be generated from WtE plants, the total amount of waste energy is multiplied by the various efficiency values of the different $\mathrm{WtE}$ technologies. The calculated values for incineration, anaerobic digestion, gasification and pyrolysis are tabulated in Table 4. It should be noted that for each technology, the amount of energy generated varies for two main reasons: (1) the different efficiencies, and (2) the different kind of waste that it can treat. For example, anaerobic digestion can only treat organic waste, which explains the low value of energy generated as compared to other technologies, since plastic waste has a high heating value and represents around $12 \%$ of waste generated in New Zealand. As a consequence, anaerobic digestion needs to be combined with a good recycling strategy, if it is to be adopted nationwide. As expected, the most sophisticated technologies (WtE-GT integrated and advanced gasification) offer the most energy generation, and further studies in this area will allow the energetic optimization of future WtE plants. However, these technologies are less mature at the moment.

Table 4. Energy generation potentials from municipal waste in New Zealand.

\begin{tabular}{cccccc}
\hline & $\begin{array}{c}\text { Incineration } \\
\text { (Conventional) }\end{array}$ & $\begin{array}{c}\text { Incineration } \\
\text { (WtE-GT Integrated) }\end{array}$ & $\begin{array}{c}\text { Anaerobic } \\
\text { Digestion }\end{array}$ & $\begin{array}{c}\text { Advanced } \\
\text { Gasification }\end{array}$ & Pyrolysis \\
\hline $\begin{array}{c}\text { Energy production } \\
\text { efficiency (\%) }\end{array}$ & $21.0 \%[47]$ & $42.0 \%[31]$ & $10.4 \%[48]$ & $35.0 \%[49]$ & $20.5 \%[50]$ \\
$\begin{array}{c}\text { Annual energy production } \\
\text { potential (GJ) }\end{array}$ & $5,806,909$ & $11,613,819$ & $1,015,671^{1}$ & $9,665,899$ & $5,661,455$ \\
\hline
\end{tabular}

${ }^{1}$ Only organic waste is treated.

\subsection{Suitability Comparison of the Technologies for New Zealand}

To analyze the suitability of the available WtE technologies in the context of New Zealand, a comparison is carried out in the following aspects: air pollution, cost (capital and maintenance), side product, capacity of production, commercial maturity, energy efficiency and type of waste to be treated.

Studies of gas emissions from each type of plants are available in the literature [32,51-53]. There are technologies to treat the various gas emissions to reduce air pollution. These, however, have financial implications. For example, although gasification plants emit less carbon dioxide than incineration plants [54], it is more expensive to treat the emission from gasification plants than that from incinerators [55]. Among all the technologies, anaerobic digestion is the least air polluting since all gases are captured to produce methane [56]. Pyrolysis is less polluting than incineration because of the absence of oxygen during the process and the lower temperature used [57]. It is also less polluting than gasification for the same reason [50].

To compare the cost of each technology, Table 5 tabulates the costs of WtE plants based on data from GIZ (German Corporation for International Cooperation) [58]. It can be seen that anaerobic 
digestion is the most economical option. Conventional incineration is relatively more economical than gasification/pyrolysis, while the advanced incineration plant is currently very costly.

Table 5. Cost estimations of various $\mathrm{WtE}$ technologies.

\begin{tabular}{ccccc}
\hline & $\begin{array}{c}\text { Incineration } \\
\text { (Conventional) }\end{array}$ & $\begin{array}{c}\text { Incineration } \\
\text { (WtE-GT Integrated) }\end{array}$ & $\begin{array}{c}\text { Anaerobic } \\
\text { Digestion }\end{array}$ & Gasification/Pyrolysis \\
\hline Annual capacity (tons) [58] & 150,000 & 150,000 & 100,000 & 250,000 \\
Investment cost (million EUR) [58] & 55 & 160 & 16 & 100 \\
Total cost (EUR/ton) & 65 & 280 & 28 & 75 \\
\hline
\end{tabular}

Regarding side products, incineration units usually recycle the bottom ash to recover metals from it and the remaining ash can be used as construction materials (aggregates) [10]. Anaerobic digestion's main side product is digestate, which can be used for fertilizer [32]. For gasification, only ashes remain from the process apart from the syngas are generated [54]. The side products of pyrolysis depend on the parameters used. The range and proportions of products is then quite varied and is constituted by unconverted carbon, charcoal, ash, pyrolysis oil and syngas [59].

Regarding the waste treatment capacities, the common scales of capacity of each technology are as follows [47]: (1) incineration can treat 1500 tons of waste per day, (2) pyrolysis and gasification can treat 10 and 100 tons of waste per day, respectively, and (3) around 500 tons of waste per day can be treated by anaerobic digestion [58]. The capacity of production obviously depends on the size of the treatment facility, but those figures give an idea of the current performances of the existing plants in the world.

In terms of the level of maturity of the technologies, waste incineration is the most mature, followed by anaerobic digestion, while pyrolysis and gasification are not yet mature [10,50].

Another aspect to consider is the energy production efficiency of each technology. It is noted that the efficiency of each technology depends on many factors such as the thermodynamic cycle employed, the scale of the plant and all the techniques used for optimization that are different for each plant. For conventional incinerators, steam turbines are commonly used and the electrical energy production efficiency is typically around 15-30\% [47]. When used to provide heating, the efficiency of incinerators can reach $90 \%$ and for combined heat and power is $40 \%$ [47]. For anaerobic digestion, the maximum efficiency of anaerobic digesters to produce biogas based on the heating values is $28 \%$ [48]. Assuming a gas turbine with an efficiency of $30-40 \%$, the overall efficiency is between $8.4-11.2 \%$. The gasification technology has an efficiency of between $10-27 \%$ or $30-40 \%$ (advanced gasification), depending on the type of turbine used [50]. Pyrolysis has an efficiency of between $16-25 \%$, assuming a gas turbine for the electricity production process [50].

In terms of the type of waste that can be treated, incineration is the most comprehensive as it can treat almost any type of waste. Gasification and pyrolysis plants may be able to treat all kind of waste with less environmental impact and at a lower cost as compared to incineration, but the technologies are less mature. Anaerobic digestion is the most limited option as it cannot treat non-biodegradable materials, such as plastic waste.

To summarize the comparison of the various aspects above, to find the most suitable technology for New Zealand, scores ranging from 0 (the worst) to 3 (the best) were assigned by ranking each of the technologies in each parameter. For example, anaerobic digestion is the most preferred option in the aspect of air pollution, followed by pyrolysis, gasification and lastly, incineration. Therefore, in the aspect of air pollution, anaerobic digestion was given a score of 3, pyrolysis got a score of 2, a score of 1 for gasification and incineration was given a zero score. Table 6 summarizes the scores of the four technologies in all the aspects considered without any special weightage for any of the parameters. The table shows that, without weightage, incineration and anaerobic digestion are generally the most attractive WtE options, followed by pyrolysis and, lastly, gasification. Incineration is attractive 
mainly because of its capacity and maturity. Anaerobic digestion is advantageous in terms of its environment-friendliness and cost.

Table 6. Comparison of WtE technologies without weightages.

\begin{tabular}{ccccc}
\hline & Incineration & Anaerobic Digestion & Gasification & Pyrolysis \\
\hline Air pollution & 0 & 3 & 1 & 2 \\
Cost & 2 & 3 & 0.5 & 0.5 \\
Side products & 1.5 & 1.5 & 0 & 3 \\
Capacity & 3 & 2 & 1 & 0 \\
Maturity & 3 & 2 & 0.5 & 0.5 \\
Energy efficiency & 1.5 & 0 & 3 & 1.5 \\
Waste type & 2 & 0 & 2 & 2 \\
\hline Total & $\mathbf{1 3}$ & $\mathbf{1 1 . 5}$ & $\mathbf{8}$ & $\mathbf{9 . 5}$ \\
\hline
\end{tabular}

In practice, New Zealand has two main concerns regarding its waste treatment strategy, i.e., environment-friendliness and economy. Therefore, more weightages should be assigned to the relevant parameters in comparison. The main parameter that is relevant to environment-friendliness is air pollution, while that for the economy is cost. A double weightage was therefore given to these two parameters. The results are presented in Table 7 . The table shows that anaerobic digestion seems to be the most attractive solution for New Zealand in general. It is both environment-friendly and economical. The technology is relatively mature. The inability of anaerobic digestion to treat non-biodegradable waste is actually consistent with New Zealand's national waste management strategy to reduce, reuse and recycle waste. It should be noted, however, that the energy production efficiency of anaerobic digestion is relatively low as compared to the alternatives. Furthermore, it is seriously lacking in its waste treatment capacity. Therefore, in order for this option to be successful in its implementation nationwide, it is crucial to ensure the effectiveness of the existing national waste management strategy to reduce, reuse and recycle.

Table 7. Comparison with special weightages on environmental and economic aspects.

\begin{tabular}{cccccc}
\hline & Weightage & Incineration & Anaerobic Digestion & Gasification & Pyrolysis \\
\hline Air pollution & 2 & 0 & 6 & 2 & 4 \\
Cost & 2 & 4 & 6 & 1 & 1 \\
Side products & 1 & 1.5 & 1.5 & 0 & 3 \\
Capacity & 1 & 3 & 2 & 1 & 0 \\
Maturity & 1 & 3 & 2 & 0.5 & 0.5 \\
Energy & 1 & 1.5 & 0 & 3 & 1.5 \\
efficiency & 1 & 2 & $\mathbf{1 7 . 5}$ & $\mathbf{9 . 5}$ & $\mathbf{1 2}$ \\
Waste type & & $\mathbf{1 5}$ & &
\end{tabular}

\section{Conclusions}

This article discusses the municipal waste management and the Waste-to-Energy (WtE) potentials in New Zealand. Globally, New Zealand generates more waste per capita as compared to other OECD countries. Moreover, the total amount of waste generated has been steadily increasing over the years and is expected to continue to rise following the country's economic and population growths. The main waste management strategy of New Zealand is currently to reduce, reuse and recycle waste, while most of the non-reusable and non-recyclable waste ends up in landfills.

Various alternative technologies are available to treat waste in a more sustainable manner. WtE options were explored in this study for possible future implementation in New Zealand. This option is attractive as it is environmentally friendly and can further reduce the country's dependency on fossil 
fuels. According to the calculation, the energy potential of waste in New Zealand was more than 30.8 PJ per year, which is more than the amount of energy from coal in the country.

Four technologies were discussed and compared: incineration, anaerobic digestion, gasification and pyrolysis. The aspects in focus were air pollution, cost, side products, waste treatment capacity, commercial maturity, energy efficiency and type of waste treated. Without any special weightage to any of the parameters, incineration is the most attractive option. It is a very mature technology and is able to treat any type of waste effectively. However, environment-friendliness and cost are especially important for New Zealand. Therefore, more weightages were given to the air pollution and cost aspects. From the comparison, it was found that anaerobic digestion seems to be the most attractive solution for the country. Anaerobic digestion plants are environment-friendly and economical. It is also consistent with New Zealand's existing waste management strategy. The major limitations of anaerobic digestion are its low energy production efficiency and its limited waste treatment capacity. It is noted, therefore, that this option has to run in tandem with an effective national strategy to reduce, reuse and recycle waste in the country.

Author Contributions: Conceptualization, A.S.; Methodology, J.-F.P. and A.S.; Data Curation, J.-F.P.; Investigation, J.-F.P.; Writing-Original Draft Preparation, J.-F.P.; Writing-Review \& Editing, A.S.; Supervision, A.S.; Project Administration, J.-F.P. and A.S.

Funding: This research received no external funding

Conflicts of Interest: The authors declare no conflicts of interest.

\section{References}

1. Solid Waste Management. Available online: http://www.worldbank.org/en/topic/urbandevelopment/ brief/solid-waste-management (accessed on 19 July 2018).

2. Hoornweg, D.; Bhada-Tata, P. What a Waste-A Global Review of Solid Waste Management; Urban Development Series Knowledge Papers; The World Bank: Washington, DC, USA, 2012; pp. 40-44.

3. Davies, A.R. Clean and green? A governance analysis of waste management in New Zealand. J. Environ. Plann. Manag. 2009, 52, 157-176. [CrossRef]

4. Estimated Resident Population of New Zealand. Available online: https://www.stats.govt.nz/topics/ population (accessed on 19 July 2018).

5. NZ Most Wasteful Country in Developed World. Available online: https://www.nzherald.co.nz/nz/news/ article.cfm?c_id=1\&objectid=11977131 (accessed on 19 July 2018).

6. The New Zealand Waste Strategy—Reducing Harm, Improving Efficiency. Available online: http:/ /www. mfe.govt.nz/sites/default/files/wastestrategy.pdf (accessed on 19 July 2018).

7. Quantity of Solid Waste Sent to Landfill Indicator Update. Available online: http:/ /www.mfe.govt.nz/more/ environmental-reporting/reporting-act/waste/solid-waste-disposal-indicator/quantity-solid-waste (accessed on 19 July 2018).

8. Cucchiella, F.; D'Adamo, I.; Gastaldi, M. Sustainable waste management: Waste to energy plant as an alternative to landfill. Energy Convers. Manag. 2017, 131, 18-31. [CrossRef]

9. Astrup, T.F.; Tonini, D.; Turconi, R.; Boldrin, A. Life cycle assessment of thermal Waste-to-Energy technologies: Review and recommendations. Waste Manag. 2015, 37, 104-115. [CrossRef] [PubMed]

10. Lombardi, L.; Carnevale, E.; Corti, A. A review of technologies and performances of thermal treatment systems for energy recovery from waste. Waste Manag. 2015, 37, 26-44. [CrossRef] [PubMed]

11. Malinauskaite, J.; Jouhara, H.; Czajczyńskab, D.; Stanchev, P.; Katsou, E.; Rostkowski, P.; Thorne, R.J.; Colón, J.; Ponsá, S.; Al-Mansour, F.; et al. Municipal solid waste management and waste-to-energy in the context of a circular economy and energy recycling in Europe. Energy 2017, 141, 128. [CrossRef]

12. Taelman, S.E.; Tonini, D.; Wandl, A.; Dewulf, J. A holistic sustainability framework for waste management in European cities: Concept development. Sustainability 2018, 10, 2184. [CrossRef]

13. Couth, R.; Trois, C. Carbon emissions reduction strategies in Africa from improved waste management: A review. Waste Manag. 2010, 30, 2336-2346. [CrossRef] [PubMed]

14. Othman, S.N.; Noor, Z.Z.; Abba, A.H.; Yusuf, R.O.; Hassan, M.A.A. Review on life cycle assessment of integrated solid waste management in some Asian countries. J. Clean. Prod. 2013, 41, 251-262. [CrossRef] 
15. Guerrero, L.A.; Maas, G.; Hogland, W. Solid waste management challenges for cities in developing countries. Waste Manag. 2013, 33, 220-232. [CrossRef] [PubMed]

16. Zhang, D.Q.; Tan, S.K.; Gersberg, R.M. Municipal solid waste management in China: Status, problems and challenges. J. Environ. Manag. 2010, 91, 1623-1633. [CrossRef] [PubMed]

17. Sharholy, M.; Ahmad, K.; Mahmood, G.; Trivedi, R.C. Municipal solid waste management in Indian cities-A review. Waste Manag. 2008, 28, 459-467. [CrossRef] [PubMed]

18. Metin, E.; Eröztürk, A.; Neyim, C. Solid waste management practices and review of recovery and recycling operations in Turkey. Waste Manag. 2003, 23, 425-432. [CrossRef]

19. Psomopoulos, C.S.; Bourka, A.; Themelis, N.J. Waste-to-energy: A review of the status and benefits in USA. Waste Manag. 2009, 29, 1718-1724. [CrossRef] [PubMed]

20. Alzate-Arias, S.; Jaramillo-Duque, A.; Villada, F.; Restrepo-Cuestas, B. Assessment of government incentives for Energy from Waste in Colombia. Sustainability 2018, 10, 1294. [CrossRef]

21. Fazeli, A.; Bakhtvar, F.; Jahanshaloo, L.; Sidik, N.A.C.; Bayat, A.E. Malaysia's stand on municipal solid waste conversion to energy: A review. Renew. Sustain. Energy Rev. 2016, 58, 1007-1016. [CrossRef]

22. Menikpura, S.N.M.; Sang-Arun, J.; Bengtsson, M. Assessment of environmental and economic performance of Waste-to-Energy facilities in Thai cities. Renew. Energy 2016, 86, 576-584. [CrossRef]

23. Ouda, O.K.M.; Raza, S.A.; Nizami, A.S.; Rehan, M.; Al-Waked, R.; Korres, N.E. Waste to energy potential: A case study of Saudi Arabia. Renew. Sustain. Energy Rev. 2016, 61, 328-340. [CrossRef]

24. Zaman, A.U. A comprehensive review of the development of zero waste management: Lessons learned and guidelines. J. Clean. Prod. 2015, 91, 12-25. [CrossRef]

25. Organisation for Economic Co-operation and Development (OECD). OECD Environmental Performance Reviews: New Zealand 2017; OECD Publishing: Paris, France, 2017; p. 23. ISBN 978-92-64-26829-6.

26. Waste: Municipal Waste, OECD Environment Statistics (Database). Available online: https://doi.org/10. 1787/ data-00601-en (accessed on 19 July 2018).

27. Perrot, J.-F. Municipal Waste Management Strategy Review and Waste-to-Energy Generation Potential in New Zealand. Master's Thesis, The University of Auckland, Auckland, New Zealand, 2018.

28. Waste Minimisation Act 2008. Available online: http://www.legislation.govt.nz/act/public/2008/0089/ latest/DLM999802.html?src=qs (accessed on 20 August 2018).

29. What about Energy from Waste? Available online: http://www.infrastructurenews.co.nz/\%EF\%BB\%BFwhat-about-energy-from-waste/ (accessed on 19 July 2018).

30. Energy in New Zealand. Available online: http://www.mbie.govt.nz/info-services/sectors-industries/ energy / energy-data-modelling/publications/energy-in-new-zealand/documents-images / energy-in-nz2017.pdf (accessed on 23 July 2018).

31. Branchini, L. Advanced Waste-To-Energy Cycles. Ph.D. Thesis, Universita di Bologna, Bologna, Italy, 2012.

32. Bosmans, A.; Vanderreydt, I.; Geysen, D.; Helsen, L. The crucial role of Waste-to-Energy technologies in enhanced landfill mining: A technology review. J. Clean. Prod. 2013, 55, 10-23. [CrossRef]

33. Scungio, M.; Buonanno, G.; Stabile, L.; Ficco, G. Lung cancer risk assessment at receptor site of a waste-to-energy plant. Waste Manag. 2016, 56, 207-215. [CrossRef] [PubMed]

34. Damgaard, A.; Riber, C.; Fruergaard, T.; Hulgaard, T.; Christensen, T.H. Life-cycle-assessment of the historical development of air pollution control and energy recovery in waste incineration. Waste Manag. 2010, 30, 1244-1250. [CrossRef] [PubMed]

35. Waste-to-Energy Plants in Europe in 2015. Available online: http://www.cewep.eu/2017/09/07/waste-toenergy-plants-in-europe-in-2015/ (accessed on 20 July 2018).

36. Valorisation Énergétique des Déchets Opportunités et Défis (In French). Available online: http://www. europarl.europa.eu/RegData/etudes/BRIE/2015/554208/EPRS_BRI(2015)554208_FR.pdf (accessed on 20 July 2018).

37. The Swedish Recycling Revolution. Available online: https://sweden.se/nature/the-swedish-recyclingrevolution/ (accessed on 20 July 2018).

38. Tong, H.; Shen, Y.; Zhang, J.; Wang, C.-H.; Ge, T.S.; Tong, Y.W. A comparative life cycle assessment on four waste-to-energy scenarios for food waste generated in eateries. Appl. Energy 2018, 225, 1143-1157. [CrossRef]

39. Ranieri, L.; Mossa, G.; Pellegrino, R.; Digiesi, S. Energy recovery from the organic fraction of municipal solid waste: A real options-based facility assessment. Sustainability 2018, 10, 368. [CrossRef] 
40. Biogas to Energy: The World Market for Biogas Plants. Available online: https://www.ecoprog.com/ fileadmin/user_upload/leseproben/extract_biogas_to_energy_ecoprog.pdf (accessed on 9 August 2016).

41. Di Matteo, U.; Nastasi, B.; Albo, A.; Garcia, D.A. Energy contribution of OFMSW (organic fraction of municipal solid waste) to energy-environmental sustainability in urban areas at small scale. Energies 2017, 10, 229. [CrossRef]

42. Overview of Biogas in NZ (WB06). Available online: https://www.biogas.org.nz/documents/resource/ WB06-biogas-overview.pdf (accessed on 23 July 2018).

43. Kumar, A.; Jones, D.D.; Hanna, M.A. Thermochemical Biomass Gasification: A Review of the Current Status of the Technology. Energies 2009, 2, 556-581. [CrossRef]

44. Zaman, A.U. Life cycle assessment of pyrolysis-gasification as an emerging municipal solid waste treatment technology. Int. J. Environ. Sci. Technol. 2013, 10, 1029-1038. [CrossRef]

45. Das, O.; Sarmah, A.K.; Bhattacharyya, D. A novel approach in organic waste utilization through biochar addition in wood/polypropylene composites. Waste Manag. 2015, 38, 132-140. [CrossRef] [PubMed]

46. Arbestain, M.C.; Jones, J.R.; Condron, L.M.; Clough, T.J. Research and application of biochar in New Zealand. In Agricultural and Environmental Applications of Biochar: Advances and Barriers; Soil Science Society of America: Washington, DC, USA, 2017; pp. 423-444. ISBN 978-0-89118-967-1.

47. World Energy Resources, Waste to Energy. Available online: https://www.worldenergy.org/wp-content/ uploads/2017/03/WEResources_Waste_to_Energy_2016.pdf (accessed on 20 July 2018).

48. Nordlander, E.; Holgersson, J.; Thorin, E.; Thomassen, M.; Jinyue, Y. Energy efficiency evaluation of two biogas plants. In Proceedings of the Third International Conference on Applied Energy, Perugia, Italy, 16-18 May 2011; pp. 1661-1674.

49. Waste Technologies: Waste to Energy Facilities. Available online: http:/ / www.wasteauthority.wa.gov.au/ media/files/documents/SWIP_Waste_to_Energy_Review.pdf (accessed on 20 August 2018).

50. Feasibility Study on Solid Waste to Energy Technological Aspects. Available online: http:/ / funginstitute. berkeley.edu/wp-content/uploads/2014/01/SolidWasteToEnergy.pdf (accessed on 23 July 2018).

51. Kim, J.K.; Oh, B.R.; Chun, Y.N.; Kim, S.W. Effects of temperature and hydraulic retention time on anaerobic digestion of food waste. J. Biosci. Bioeng. 2006, 102, 328-332. [CrossRef] [PubMed]

52. Arena, U. Process and technological aspects of municipal solid waste gasification. Waste Manag. 2012, 32, 625-639. [CrossRef] [PubMed]

53. Beylot, A.; Hochar, A.; Michel, P.; Descat, M.; Ménard, Y.; Villeneuve, J. Municipal solid waste incineration in France: An overview of air pollution control techniques, emissions, and energy efficiency. J. Ind. Ecol. 2017, 1-11. [CrossRef]

54. Kumar, A.; Samadder, S.R. A review on technological options of waste to energy for effective management of municipal solid waste. Waste Manag. 2017, 69, 407-422. [CrossRef] [PubMed]

55. Matsakasa, L.; Gao, Q.; Jansson, S.; Rova, U.; Christakopoulos, P. Green conversion of municipal solid wastes into fuels and chemicals. Electron. J. Biotechnol. 2017, 26, 69-83. [CrossRef]

56. Li, Y.; Park, S.Y.; Zhu, J. Solid-state anaerobic digestion for methane production from organic waste. Renew. Sustain. Energy Rev. 2011, 15, 821-826. [CrossRef]

57. Samoladab, M.C.; Zabaniotou, A.A. Comparative assessment of municipal sewage sludge incineration, gasification and pyrolysis for a sustainable sludge-to-energy management in Greece. Waste Manag. 2014, 34, 411-420. [CrossRef] [PubMed]

58. Waste-to-Energy Options in Municipal Solid Waste Management. Available online: https://www.giz.de/ en/downloads/GIZ_WasteToEnergy_Guidelines_2017.pdf (accessed on 23 July 2018).

59. Czajczyńska, D.; Anguilanoc, L.; Ghazald, H.; Krzyżyńsk, R.; Reynold, A.J.; Spencer, N.; Jouhara, H. Potential of pyrolysis processes in the waste management sector. Therm. Sci. Eng. Prog. 2017, 3, 171-197. [CrossRef]

(C) 2018 by the authors. Licensee MDPI, Basel, Switzerland. This article is an open access article distributed under the terms and conditions of the Creative Commons Attribution (CC BY) license (http://creativecommons.org/licenses/by/4.0/). 